\title{
Seroepidemiology of chlamydia in Costa Rica
}

\author{
K M Vetter, R C Barnes, M W Oberle, L Rosero-Bixby, J Schachter
}

\begin{abstract}
A population-based study of the seroepidemiology of chlamydia was performed among a nationally representative sample of 760 Costa Rican women aged 25 to 59 years. Interviews and sera collection were completed between September 1984 and February 1985. The overall seroprevalence of chlamydial antibodies among these women was $56 \cdot 1 \%$. Women 25 to 39 years of age had a seroprevalence of $51.1 \%$, while women 40 to 59 years of age had a seroprevalence of $64 \cdot 2 \%$. Women who reported no prior sexual activity had a seroprevalence rate of $48.6 \%$, compared with a seroprevalence rate of $80.7 \%$ among women who reported three or more lifetime sexual partners. The geometric mean titre (GMT) of seropositive women ranged from 34.4 among the women who reported no prior sexual activity to $155 \cdot 0$ among the women with three or more lifetime sexual partners. Seropositivity was more consistently associated with sexual activity than with age. Women with serological evidence of past Herpes simplex virus type 2 (HSV-2) or syphilis infection were more likely to be seropositive than were
\end{abstract}

Division of Public Health, Emory University, Atlanta, Georgia, USA

K M Vetter

US Department of Health and Human Services, Public Health Service, Centers for Disease Control, Center for Infectious Diseases, STD Laboratory Program, Atlanta, Georgia, USA

R C Barnes

US Department of Health and Human Services, Public Health Service, Centers for Disease Control, Center for Chronic Disease Prevention and Health Promotion, Division of Reproductive Health, Atlanta, Georgia, USA

$M$ W Oberle

Instituto de Investigaciones en Salud, University of Costa Rica, San Jose, Costa Rica

L Rosero-Bixby

Departments of Epidemiology and Laboratory Medicine, University of California, San Francisco, San Francisco, California, USA

J Schachter women without evidence of exposure to these sexually transmitted diseases, even when controlled for age and the number of lifetime sexual partners.

The seropositivity among never sexually active women indicates the probable presence of Chlamydia pneumoniae infections, while the high seroprevalence of chlamydial antibodies among the sexually active women suggests that sexually transmitted Chlamydia trachomatis infections represent a public health problem not previously quantified in Costa Rica. Further seroepidemiological and/ or culture studies are warranted to determine the incidence and prevalence of sexually transmitted chlamydial infection among men and younger women.

In developed countries, Chlamydia trachomatis has become a focus of public health concern because $C$ trachomatis infections occur more frequently than any other sexually transmitted disease (STD). Chlamydial infection rates in the United States and Great Britain appear to have increased over the last decade. ${ }^{12}$ Acute salpingitis in females caused by $C$ trachomatis may lead to infertility and/or ectopic pregnancy. $C$ trachomatis can also cause inclusion conjunctivitis and pneumonia of the newborn through perinatal transmission of the infection. Only limited information on the prevalence and trends of chlamydial STDs in developing countries is available.

Few population-based or population-representative studies examining the seroprevalence of chlamydial antibodies have been published. Population-based serological studies with detailed demographic information, and data on reproductive health and sexual habits are not available. We report here a study of the seroprevalence of chlamydial antibodies in Costa Rican women 25 to 59 years of age.

\section{Methods}

POPULATION

We studied a nationally representative sample of Costa Rican women 25 to 59 years of age who were previously enrolled as controls in a case-control 
study of contraceptive use and the risk of cervical and breast cancer in Costa Rica. ${ }^{3-5}$ These women were selected through a household survey using a multistage, probability sample design, with a sampling frame based on the 1984 Costa Rican census. The sampling frame excluded sparsely populated regions representing $5 \%$ of the population. Some five-year age groups were oversampled for the methodologic design of the cancer study.

\section{INTERVIEWS AND SERUM COLLECTION}

The survey obtained medical, reproductive, and sexual histories using a modified version of the standardised questionnaire from the US Centers for Disease Control's Cancer and Steroid Hormone Study. ${ }^{6}$ Trained female interviewers administered the questionnaire between September 1984 and February 1985. Shortly after the interview, a laboratory technician collected blood specimens from consenting interviewees.

\section{LABORATORY DETERMINATIONS}

We determined IgG titres of anti-chlamydial antibody using the simplified microimmunofluorescence (MIF) technique. ${ }^{7}$ We considered a titre greater than or equal to $1: 16$ positive for chlamydial antibody. The sera were also tested for antibodies to syphilis and Herpes simplex type 2 (HSV-2), using the microhemagglutination assay for Treponema pallidum (MHA-TP) ${ }^{8}$ and a type-specific glycoprotein antigen test, ${ }^{9}$ respectively.

\section{ANALYSIS}

We analysed seroprevalence by: age; number of lifetime sexual partners; serological evidence of prior HSV-2 or syphilis infection; history of infertility-a self-report of any unsuccessful attempt to become pregnant for 24 consecutive months; history of pelvic inflammatory disease (PID)-a self-report of a doctor's diagnosis of infection of the uterus or tubes or inflammation of the pelvis; region of residence; and education as an indicator of socioeconomic status.
In calculating seroprevalence we used a weighting scheme based on the inverse of the sampling fraction to compensate for the oversampling of some 5 year age intervals. The standard errors used to calculate confidence limits were estimated using a Taylor series linearisation, as performed by SESUDAAN, a SAS procedure, ${ }^{10}$ which accounts for both ageweighting and the cluster sample design.

To control for the possible effect of age and the number of lifetime sexual partners on the seroprevalence rates by other characteristics, we stratified the results into two age groups ( 25 to 39 and 40 to 59 years) and two groups based on the number of lifetime sexual partners (less than two and two or more). We calculated the geometric mean titre (GMT) of chlamydial antibody of seropositive women using unweighted data.

\section{Results}

Of the 935 women eligible for the study, $870(93.0 \%)$ consented to an interview and 767 of those interviewed permitted the technician to draw a blood sample. Women for whom no serum was available were similar to those with a serum specimen with regard to age, parity, region of residence, education, and economic status. ${ }^{11}$ We obtained valid chlamydial antibody titre results for 760 women. These 760 women $(87.4 \%$ of those interviewed) constitute our nationally representative study population.

The overall weighted seroprevalence of chlamydial antibody was $56.1 \%$ (table 1 ). Titres ranged from 0 to $1: 4,096$. Among women less than 40 years of age seroprevalence was $51.1 \%$, while for women 40 years of age and over seroprevalence was $64.2 \%$ (table 2). Seroprevalence increased with increasing age up to 49 years (table 1). When we controlled for sexual activity, in each age group women with two or more lifetime sexual partners had higher seropositivity rates than women with less than two lifetime sexual partners. However, the stratification did not change the general pattern in seroprevalence by age. Among

Table 1 Chlamydial antibody status: Percent seropositive and geometric mean titre (GMT) by age by number of lifetime sexual partners among Costa Rican women, 25-59 years of age, 1984-85

\begin{tabular}{|c|c|c|c|c|c|c|c|c|c|c|c|c|}
\hline \multirow[b]{3}{*}{$\begin{array}{l}\text { Age } \\
\text { group } \\
(y r)\end{array}$} & \multirow{2}{*}{\multicolumn{4}{|c|}{ All women }} & \multicolumn{8}{|c|}{ Number of sexual partners $\dagger$} \\
\hline & & & & & \multicolumn{4}{|l|}{$0-1$} & \multicolumn{4}{|l|}{$2+$} \\
\hline & $\begin{array}{l}\text { Percent } \\
\text { positive }\end{array}$ & $(N)$ & $\begin{array}{l}95 \% \\
\text { Confidence } \\
\text { interval }\end{array}$ & $\begin{array}{l}G M T \\
\text { positive } \\
\text { titres }\end{array}$ & $\begin{array}{l}\text { Percent } \\
\text { positive }\end{array}$ & $(N)$ & $\begin{array}{l}95 \% \\
\text { Confidence } \\
\text { interval }\end{array}$ & $\begin{array}{l}\text { GMT } \\
\text { positive } \\
\text { titres }\end{array}$ & $\begin{array}{l}\text { Percent } \\
\text { positive }\end{array}$ & $(N)$ & $\begin{array}{l}95 \% \\
\text { Confidence } \\
\text { interval }\end{array}$ & $\begin{array}{l}\text { GMT } \\
\text { positive } \\
\text { titres }\end{array}$ \\
\hline $\begin{array}{l}25-29 \\
30-39 \\
40-49 \\
50-59\end{array}$ & $\begin{array}{l}48 \cdot 3 \\
53 \cdot 3 \\
69 \cdot 1 \\
58 \cdot 1\end{array}$ & $\begin{array}{l}(118) \\
(270) \\
(193) \\
(179)\end{array}$ & $\begin{array}{l}{[38 \cdot 6-58 \cdot 1]} \\
{[46 \cdot 8-59 \cdot 9]} \\
{[62 \cdot 4-75 \cdot 9]} \\
{[50 \cdot 6-65 \cdot 6]}\end{array}$ & $\begin{array}{r}84 \cdot 7 \\
102 \cdot 1 \\
73 \cdot 4 \\
72 \cdot 6\end{array}$ & $\begin{array}{l}44 \cdot 0 \\
44 \cdot 9 \\
63 \cdot 9 \\
52 \cdot 6\end{array}$ & $\begin{array}{l}(84) \\
(187) \\
(125) \\
(137)\end{array}$ & $\begin{array}{l}{[33 \cdot 0-55 \cdot 0]} \\
{[37 \cdot 0-52 \cdot 9]} \\
{[55 \cdot 5-72 \cdot 3]} \\
{[43 \cdot 9-61 \cdot 2]}\end{array}$ & $\begin{array}{l}59 \cdot 4 \\
82 \cdot 7 \\
56 \cdot 6 \\
58 \cdot 1\end{array}$ & $\begin{array}{l}58 \cdot 8 \\
72 \cdot 0 \\
78 \cdot 3 \\
76 \cdot 2\end{array}$ & $\begin{array}{l}(34) \\
(82) \\
(67) \\
(42)\end{array}$ & $\begin{array}{l}{[40 \cdot 3-77 \cdot 4]} \\
{[62 \cdot 3-81 \cdot 6]} \\
{[68 \cdot 1-88 \cdot 5]} \\
{[63 \cdot 1-89 \cdot 3]}\end{array}$ & $\begin{array}{l}163.1 \\
142.3 \\
107.6 \\
119.9\end{array}$ \\
\hline Total & $56 \cdot 1$ & $(760)$ & {$[51 \cdot 9-60 \cdot 3]$} & & $49 \cdot 8$ & (533) & {$[45 \cdot 0-54 \cdot 6]$} & & 70.5 & (225) & {$[63 \cdot 6-77 \cdot 5]$} & \\
\hline
\end{tabular}

^Percent seropositive is age weighted.

$\dagger$ Two women with an unknown number of lifetime sexual partners were excluded from the analysis. 
Table 2 Chlamydial antibody status: Percent seropositive and geometric mean titre (GMT) by number of lifetime sexual partners by age among Costa Rican women, 25-59 years of age, 1984-85

\begin{tabular}{|c|c|c|c|c|c|c|c|c|c|c|c|c|}
\hline \multirow[b]{3}{*}{$\begin{array}{l}\text { Number of } \\
\text { lifetime } \\
\text { sexual } \\
\text { partners }\end{array}$} & \multirow{2}{*}{\multicolumn{4}{|c|}{ All women }} & \multicolumn{8}{|l|}{ Age (yr) } \\
\hline & & & & & \multicolumn{4}{|l|}{$25-39$} & \multicolumn{4}{|l|}{$40-59$} \\
\hline & $\begin{array}{l}\text { Percent } \\
\text { positive }\end{array}$ & $(N)$ & $\begin{array}{l}95 \% \\
\text { Confidence } \\
\text { interval }\end{array}$ & $\begin{array}{l}\text { GMT } \\
\text { positive } \\
\text { titres }\end{array}$ & $\begin{array}{l}\text { Percent } \\
\text { positive }\end{array}$ & $(N)$ & $\begin{array}{l}95 \% \\
\text { Confidence } \\
\text { interval }\end{array}$ & $\begin{array}{l}\text { GMT } \\
\text { positive } \\
\text { titres }\end{array}$ & $\begin{array}{l}\text { Percent } \\
\text { positive }\end{array}$ & $(N)$ & $\begin{array}{l}95 \% \\
\text { Confidence } \\
\text { interval }\end{array}$ & $\begin{array}{l}\text { GMT } \\
\text { positive } \\
\text { titres }\end{array}$ \\
\hline $\begin{array}{l}0 \\
1 \\
2 \\
3+\end{array}$ & $\begin{array}{l}48 \cdot 6 \\
49 \cdot 9 \\
63 \cdot 3 \\
80 \cdot 7\end{array}$ & $\begin{array}{r}(36) \\
(497) \\
(133) \\
(92)\end{array}$ & $\begin{array}{l}{[32 \cdot 9-64 \cdot 2]} \\
{[45 \cdot 1-54 \cdot 6]} \\
{[53 \cdot 4-73 \cdot 1]} \\
{[71 \cdot 9-89 \cdot 5]}\end{array}$ & $\begin{array}{r}34 \cdot 4 \\
67 \cdot 6 \\
108 \cdot 3 \\
155 \cdot 0\end{array}$ & $\begin{array}{l}38 \cdot 2 \\
45 \cdot 1 \\
57 \cdot 9 \\
77 \cdot 1\end{array}$ & $\begin{array}{r}(22) \\
(249) \\
(65) \\
(51)\end{array}$ & $\begin{array}{l}{[18 \cdot 1-58 \cdot 4]} \\
{[38 \cdot 1-52 \cdot 0]} \\
{[44 \cdot 0-71 \cdot 7]} \\
{[64 \cdot 4-89 \cdot 8]}\end{array}$ & $\begin{array}{r}32 \cdot 0 \\
80 \cdot 0 \\
115 \cdot 1 \\
187 \cdot 4\end{array}$ & $\begin{array}{l}73 \cdot 9 \\
57 \cdot 5 \\
71 \cdot 4 \\
87 \cdot 2\end{array}$ & $\begin{array}{r}(14) \\
(248) \\
(68) \\
(41)\end{array}$ & $\begin{array}{l}{[51 \cdot 9-95 \cdot 9]} \\
{[51 \cdot 3-63 \cdot 6]} \\
{[60 \cdot 4-82 \cdot 3]} \\
{[76 \cdot 8-97 \cdot 7]}\end{array}$ & $\begin{array}{r}36 \cdot 8 \\
59 \cdot 2 \\
103 \cdot 1 \\
125 \cdot 6\end{array}$ \\
\hline Total $†$ & $56 \cdot 1$ & $(760)$ & {$[51 \cdot 9-60 \cdot 3]$} & & $51 \cdot 1$ & (388) & {$[45 \cdot 1-57 \cdot 0]$} & & $64 \cdot 2$ & (372) & {$[59 \cdot 1-69 \cdot 4]$} & \\
\hline
\end{tabular}

^Percent seropositive is age weighted.

†Total includes two women with an unknown number of lifetime sexual partners who are not shown separately.

all seropositive women and seropositive women with less than two lifetime sexual partners those 30 to 39 years old had the highest GMT; however, among seropositive women with two or more lifetime sexual partners those 25 to 29 years old had the highest GMT (table 1).

Chlamydial seropositivity increased from $48.6 \%$ for women reporting no previous sexual experience to $80.7 \%$ for those with three or more lifetime sexual partners (table 2). Stratification of the women into two age groups resulted in lower seropositivity rates for women less than 40 years of age at each sexual partner level. However, the pattern of increasing seropositivity with increasing number of lifetime sexual partners remained when the small group of older, never sexually active women was excluded (table 2). The GMT of seropositive women increased from 34.4 for women who reported no coitus to 155.0 for women with three or more lifetime sexual partners (table 2). When we controlled for age, within each sexual partner group, women 40 years and over had lower GMTs than women less than 40 years of age, except the small group of women who were never sexually active. However, the pattern of increasing
GMT with an increasing number of lifetime sexual partners did not change (table 2).

Serological evidence of prior HSV-2 or syphilis infection were associated with similar increases in chlamydial seropositivity (table 3 ) even when we controlled for age and the number of lifetime sexual partners.

Women who reported a history of prior PID did not have higher seropositivity rates than women who denied a history; however, the GMT of seropositive women who reported a history of PID was $110 \cdot 2$ whereas for seropositive women who denied a history of PID the GMT was 79.6 (table 4). The GMT of seropositive women who reported a history of infertility was 96.3 while for seropositive women who denied a history of infertility the GMT was 82.0. A history of infertility was associated with increased chlamydial seroprevalence only in women 40 years of age and over, and women with two or more lifetime sexual partners (data not shown).

Seropositivity varied with educational level. Although the pattern of seropositivity varied slightly with age and the number of lifetime sexual partners, women with a university education generally had the

Table 3 Chlamydial antibody status: Percent seropositive ${ }^{\star}$ by syphilis and herpes simplex virus type-2 (HSV-2) antibody status by age and by number of lifetime sexual partners among Costa Rican women, 25-59 years of age, 1984-85

\begin{tabular}{|c|c|c|c|c|c|c|}
\hline \multirow[b]{3}{*}{$\begin{array}{l}\text { Serology } \\
\text { results }\end{array}$} & \multirow{2}{*}{\multicolumn{3}{|c|}{ All women }} & \multicolumn{3}{|l|}{ Age (yr) } \\
\hline & & & & \multicolumn{3}{|l|}{$25-39$} \\
\hline & $\begin{array}{l}\text { Percent } \\
\text { positive }\end{array}$ & $(N)$ & $\begin{array}{l}95 \% \\
\text { Confidence } \\
\text { interval }\end{array}$ & $\begin{array}{l}\text { Percent } \\
\text { positive }\end{array}$ & $(N)$ & $\begin{array}{l}95 \% \\
\text { Confidence } \\
\text { interval }\end{array}$ \\
\hline $\begin{array}{l}\text { Syphilis } \\
\text { Negative } \\
\text { Positive }\end{array}$ & $\begin{array}{l}54 \cdot 5 \\
79 \cdot 2\end{array}$ & $\begin{array}{r}(706) \\
(54)\end{array}$ & $\begin{array}{l}{[50 \cdot 1-58 \cdot 8]} \\
{[66 \cdot 2-92 \cdot 3]}\end{array}$ & $\begin{array}{l}50 \cdot 2 \\
68 \cdot 0\end{array}$ & $\begin{array}{r}(369) \\
(19)\end{array}$ & $\begin{array}{l}{[44 \cdot 0-56 \cdot 4]} \\
{[45 \cdot 3-90 \cdot 8]}\end{array}$ \\
\hline $\begin{array}{c}\text { HSV-2 } \\
\text { Negative } \\
\text { Positive }\end{array}$ & $\begin{array}{l}45 \cdot 8 \\
71 \cdot 3\end{array}$ & $\begin{array}{l}(441) \\
(312)\end{array}$ & $\begin{array}{l}{[40 \cdot 3-51 \cdot 3]} \\
{[65 \cdot 6-77 \cdot 0]}\end{array}$ & $\begin{array}{l}40 \cdot 8 \\
69 \cdot 0\end{array}$ & $\begin{array}{l}(241) \\
(144)\end{array}$ & $\begin{array}{l}{[33 \cdot 4-48 \cdot 2]} \\
{[60 \cdot 5-77 \cdot 5]}\end{array}$ \\
\hline
\end{tabular}


Table 4 Chlamydial antibody status: Percent seropositive ${ }^{\star}$ and GMT by history of infertility and PID among Costa Rican women, 25-59 years of age, 1984-85

\begin{tabular}{|c|c|c|c|c|}
\hline \multirow[b]{2}{*}{ History of } & \multicolumn{4}{|c|}{ All women } \\
\hline & $\begin{array}{l}\text { Percent } \\
\text { positive }\end{array}$ & $(N)$ & $\begin{array}{l}95 \% \\
\text { Confidence } \\
\text { interval }\end{array}$ & $\begin{array}{l}G M T \\
\text { positive } \\
\text { titres }\end{array}$ \\
\hline $\begin{array}{l}\text { Infertility } \\
\text { Yes } \\
\text { No }\end{array}$ & $\begin{array}{l}63 \cdot 4 \\
55 \cdot 5\end{array}$ & $\begin{array}{r}(59) \\
(701)\end{array}$ & $\begin{array}{l}{[49 \cdot 1-77 \cdot 7]} \\
{[51 \cdot 2-59 \cdot 7]}\end{array}$ & $\begin{array}{l}96 \cdot 3 \\
82.0\end{array}$ \\
\hline $\begin{array}{c}\text { PID† } \\
\text { Yes } \\
\text { No }\end{array}$ & $\begin{array}{l}53 \cdot 4 \\
56 \cdot 6\end{array}$ & $\begin{array}{r}(95) \\
(661)\end{array}$ & $\begin{array}{l}{[43 \cdot 4-63 \cdot 6]} \\
{[52 \cdot 1-61 \cdot 0]}\end{array}$ & $\begin{array}{r}110.2 \\
79.6\end{array}$ \\
\hline
\end{tabular}

$\star$ Percent seropositive is age weighted.

†Four women with an unknown history of PID were excluded from the analysis.

lowest rates of seropositivity, whereas women with no formal education generally had the highest seropositivity rates (table 5 ).

We found differences in seropositivity rates by region of residence, which remained when we controlled for age and the number of lifetime sexual partners of the women. Among all women, those from San José and the urban areas outside of the central valley (principally the port cities of Limón and Puntarenas) had the highest seroprevalence rates $(59.9 \%$ and $68.6 \%$ respectively). When we stratified by age and by number of sexual partners, the highest seroprevalence was always among women from one of these two regions (data not shown).

\section{Discussion}

We found a high seroprevalence of chlamydial antibody among Costa Rican women $(56 \cdot 1 \%)$. This seroprevalence rate is in the mid-range of seroprevalence rates $(12 \%-91 \%)$ of other studies of selected female populations in developing countries. ${ }^{12-15}$ In developed countries, chlamydial seroprevalence studies have found seroprevalence rates of $17 \%-27 \%$. $^{16-18}$
Antibody to chlamydia may be acquired from sexually transmitted $C$ trachomatis infections, trachoma, ornithosis, and respiratory infections from $C$ pneumoniae (strain TWAR), ${ }^{19-21}$ or, perhaps, from perinatally acquired $C$ trachomatis infections. Trachoma is not recognised as a public health problem in Costa Rica. Data from other studies suggest that the persistence of perinatally acquired antibodies would not contribute significantly to seropositivity in the age groups st"died. ${ }^{22-24}$ Prior infection by $C$ psittaci might be resp nsible for some of the antibody in this study; howev r, it is unlikely that exposure to avian strains of $C_{j}$ sittaci is responsible for much of the seroprevalen 2 as clinical ornithosis has not been recognised in large proportions of the population in Costa Rica.

$C$ pneumoniae infections are probably responsible for some of the seropositivity in our study. Although the degree (f cross-reactivity to $C$ trachomatis as measured by our MIF is uncertain, we suspect that a considerable amount of the antibody detected is a result of $C$ pmeumoniae infections. ${ }^{25}$ No studies of $C$ pneumoniae in Costa Rica are known to the authors. In the United States and Denmark, antibody prevalence to $C$ pneumoniae increases with age, with up to $40 \%$ of adults seropositive. ${ }^{26}$ In this study, a high proportion ( $48.6 \%$ ) of the 36 women reporting no coitus had positive chlamydial antibody titres. San Joaquin et al ${ }^{23}$ reported a $43.2 \%$ seropositivity rate among 9 to 11 year olds in Oklahoma, and Black et al ${ }^{27}$ reported a $33.3 \%$ seropositivity rate for girls of the same age in San Francisco. In a study of female college students $23 \%$ of those who reported no prior sexual experience were found to be seropositive. ${ }^{28}$ Of interest, the GMT of nonsexually active seropositive women in our study (34.4) was considerably lower than that of the sexually active seropositive population, which ranged from 67.6 to 155.0 (table 2).

Seropositivity in women reporting no sexual activity may reflect misclassification of the women due to inaccurate information regarding previous

\begin{tabular}{|c|c|c|c|c|c|c|c|c|}
\hline \multirow{2}{*}{\multicolumn{3}{|c|}{$0-59$}} & \multicolumn{6}{|c|}{ Number of sexual partnerst } \\
\hline & & & \multicolumn{3}{|l|}{$0-1$} & \multicolumn{3}{|l|}{$2+$} \\
\hline $\begin{array}{l}\text { 'ercent } \\
\text { ositive }\end{array}$ & (N) & $\begin{array}{l}95 \% \\
\text { Confidence } \\
\text { interval }\end{array}$ & $\begin{array}{l}\text { Percent } \\
\text { positive }\end{array}$ & $(N)$ & $\begin{array}{l}95 \% \\
\text { Confidence } \\
\text { interval }\end{array}$ & $\begin{array}{l}\text { Percent } \\
\text { positive }\end{array}$ & $(N)$ & $\begin{array}{l}95 \% \\
\text { Confidence } \\
\text { interval }\end{array}$ \\
\hline $\begin{array}{l}1 \cdot 7 \\
9 \cdot 1\end{array}$ & $\begin{array}{r}(337) \\
(35)\end{array}$ & $\begin{array}{l}{[56 \cdot 3-67 \cdot 1]} \\
{[78 \cdot 8-99 \cdot 4]}\end{array}$ & $\begin{array}{l}48 \cdot 6 \\
79 \cdot 5\end{array}$ & $\begin{array}{r}(511) \\
(22)\end{array}$ & $\begin{array}{l}{[43 \cdot 6-53 \cdot 6]} \\
{[60 \cdot 2-98 \cdot 8]}\end{array}$ & $\begin{array}{l}69 \cdot 3 \\
79 \cdot 0\end{array}$ & $\begin{array}{r}(193) \\
(32)\end{array}$ & $\begin{array}{l}{[61 \cdot 8-76 \cdot 8]} \\
{[63 \cdot 1-95 \cdot 0]}\end{array}$ \\
\hline $\begin{array}{l}5 \cdot 3 \\
1.4\end{array}$ & $\begin{array}{l}(200) \\
(168)\end{array}$ & $\begin{array}{l}{[47 \cdot 8-62 \cdot 9]} \\
{[67 \cdot 8-81 \cdot 0]}\end{array}$ & $\begin{array}{l}43.9 \\
63.9\end{array}$ & $\begin{array}{l}(365) \\
(165)\end{array}$ & $\begin{array}{l}{[37 \cdot 7-50 \cdot 0]} \\
{[55 \cdot 8-72 \cdot 0]}\end{array}$ & $\begin{array}{l}54 \cdot 0 \\
79.5\end{array}$ & $\begin{array}{l}(75) \\
(146)\end{array}$ & $\begin{array}{l}{[41 \cdot 4-66 \cdot 7]} \\
{[72 \cdot 4-86 \cdot 5]}\end{array}$ \\
\hline
\end{tabular}


Table 5 Chlamydial antibody status: Percent seropositive by educational level by age and by number of lifetime sexual partners among Costa Rican women, 25-59 years of age, 1984-85

\begin{tabular}{|c|c|c|c|c|c|c|}
\hline \multirow[b]{3}{*}{$\begin{array}{l}\text { Educational } \\
\text { level }\end{array}$} & \multirow{2}{*}{\multicolumn{3}{|c|}{ All women }} & \multicolumn{3}{|l|}{$\operatorname{Age}(y r)$} \\
\hline & & & & \multicolumn{3}{|l|}{$25-39$} \\
\hline & $\begin{array}{l}\text { Percent } \\
\text { positive }\end{array}$ & $(N)$ & $\begin{array}{l}95 \% \\
\text { Confidence } \\
\text { interval }\end{array}$ & $\begin{array}{l}\text { Percent } \\
\text { positive }\end{array}$ & $(N)$ & $\begin{array}{l}95 \% \\
\text { Confidence } \\
\text { interval }\end{array}$ \\
\hline $\begin{array}{l}\text { None } \\
\text { Primary Incomplete } \\
\text { Primary Complete } \\
\text { Secondary } \\
\text { University }\end{array}$ & $\begin{array}{l}65 \cdot 0 \\
58 \cdot 3 \\
54 \cdot 2 \\
56 \cdot 3 \\
45 \cdot 7\end{array}$ & $\begin{array}{r}(79) \\
(257) \\
(185) \\
(170) \\
(69)\end{array}$ & $\begin{array}{l}{[53 \cdot 4-76 \cdot 6]} \\
{[52 \cdot 0-64 \cdot 9]} \\
{[46 \cdot 1-62 \cdot 3]} \\
{[48 \cdot 9-63 \cdot 8]} \\
{[33 \cdot 6-57 \cdot 7]}\end{array}$ & $\begin{array}{l}66 \cdot 5 \\
51 \cdot 1 \\
48 \cdot 8 \\
56 \cdot 0 \\
35 \cdot 3\end{array}$ & $\begin{array}{r}(23) \\
(89) \\
(111) \\
(122) \\
(43)\end{array}$ & $\begin{array}{l}{[46 \cdot 4-86 \cdot 6]} \\
{[39 \cdot 9-62 \cdot 3]} \\
{[38 \cdot 6-59 \cdot 0]} \\
{[47 \cdot 6-64 \cdot 5]} \\
{[19 \cdot 7-50 \cdot 9]}\end{array}$ \\
\hline
\end{tabular}

*Percent seropositive is age weighted.

† Two women with an unknown number of lifetime sexual partners were excluded from the analysis.

sexual experience. In a separate analysis of our study population, $6.4 \%$ of all women were found to be reactive for $T$ pallidum by MHA-TP; however, none of the women who reported no coitus were reactive (Larsen SA, unpublished data). Exposure to $C$ pneumoniae may explain a large proportion of the sexually inexperienced women found to have chlamydial antibody in this study.

Despite the evidence for nonsexually transmitted chlamydial infections in our study population, there is also considerable evidence of sexually transmitted chlamydia. The number of lifetime sexual partners was the characteristic most consistently associated with high seroprevalence. As the number of lifetime sexual partners increased, seroprevalence increased, a pattern found with most STDs. The GMT also increased as the number of lifetime sexual partners increased. This could reflect the greater risk of complicated and/or multiple infections with additional partners, as complicated infections and multiple episodes usually result in higher persistent antibody concentrations than do uncomplicated infections or a single episode. ${ }^{29}$

In addition to the dose-response pattern of increasing antibody prevalence and levels with an increasing number of lifetime sexual partners, we found that HSV-2 and syphilis seropositivity were associated with about a one third increase in chlamydial seropositivity. We would expect women with evidence of one STD to be more likely to show evidence of another STD.

There was no consistent association of chlamydial antibody with a history of PID or infertility. The GMT of seropositive women who reported PID was greater than the GMT of those seropositive women who denied a history of PID; however, there was no increase in chlamydial seropositivity for those women who reported a history of PID compared with those who did not. The lack of correlation between positive titres and a history of PID may be a result of inaccurate reporting of PID due to misunderstanding of the term, the subclinical nature of much chlamydial PID, or the presence of chlamydial antibodies not acquired from sexually transmitted infections. The reported history of PID in this study population $(12.8 \%)$ is similar to that reported in the United States. ${ }^{30}$

The lack of definitive information on the natural history of chlamydial antibody as well as the crosssectional nature of this study limit speculation regarding the reasons for variation in seroprevalence by age. The differences in seroprevalence and antibody levels by age could represent the influences of: (1) the incidence of infection among cohorts of women, (2) the varying risk of exposure to chlamydial infection with age, (3) the differing rates of infection which result in high antibody titres (such as salpingitis), and/or (4) the changes in antibody levels for individual women over time.

Longitudinal studies could better define the variation of chlamydial antibody with age. Additional cross-sectional studies could provide valuable information for interpretation of results if their designs included men and women less than 25 years of age in the study population, as well as additional information on the sexual habits of the study participants and their partners.

Our results suggest that in Costa Rica, $C$ pneumoniae infections are probably common and that $C$ trachomatis is an important agent of sexually transmitted infections. In a study of two Costa Rican clinic populations, the prevalence of culture-confirmed genital chlamydial infections was low: $2.9 \%$ in men visiting an STD clinic and $0.58 \%$ among women visiting a family planning clinic for non-STD reasons. ${ }^{31}$ The relatively low prevalence may be due to the inherent difficulties of chlamydial culture. A recent case-control study in Costa Rica found that $C$ trachomatis was responsible for $33 \%$ of hospitalised cases of infant pneumonia. ${ }^{32}$

The information provided by this and the other Costa Rican chlamydia studies indicates the need to gather further data to enable future development of a chlamydial control program. Population-based studies of $C$ trachomatis genital infections could provide estimates of current rates of sexually trans- 


\begin{tabular}{|c|c|c|c|c|c|c|c|c|}
\hline-59 & & & \multicolumn{6}{|c|}{ Number of sexual partners $\dagger$} \\
\hline $\begin{array}{l}\text { :rcent } \\
\text { sitive }\end{array}$ & $(N)$ & $\begin{array}{l}95 \% \\
\text { Confidence } \\
\text { interval }\end{array}$ & $\begin{array}{l}\text { Percent } \\
\text { positive }\end{array}$ & $(N)$ & $\begin{array}{l}95 \% \\
\text { Confidence } \\
\text { interval }\end{array}$ & $\begin{array}{l}\text { Percent } \\
\text { positive }\end{array}$ & $(N)$ & $\begin{array}{l}95 \% \\
\text { Confidence } \\
\text { interval }\end{array}$ \\
\hline $\begin{array}{l}.2 \\
.0 \\
.7 \\
.5 \\
.1\end{array}$ & $\begin{array}{r}(56) \\
(168) \\
(74) \\
(48) \\
(26)\end{array}$ & $\begin{array}{l}{[50 \cdot 8-77 \cdot 5]} \\
{[56 \cdot 6-71 \cdot 4]} \\
{[55 \cdot 1-78 \cdot 2]} \\
{[44 \cdot 1-70 \cdot 9]} \\
{[52 \cdot 9-89 \cdot 3]}\end{array}$ & $\begin{array}{l}58 \cdot 2 \\
50 \cdot 2 \\
48 \cdot 3 \\
51 \cdot 5 \\
43 \cdot 3\end{array}$ & $\begin{array}{r}(43) \\
(172) \\
(128) \\
(130) \\
(60)\end{array}$ & $\begin{array}{l}{[41 \cdot 4-74 \cdot 9]} \\
{[42 \cdot 0-58 \cdot 5]} \\
{[39 \cdot 2-57 \cdot 4]} \\
{[42 \cdot 3-60 \cdot 7]} \\
{[30 \cdot 0-56 \cdot 7]}\end{array}$ & $\begin{array}{l}72.6 \\
73.6 \\
67.2 \\
70.7 \\
59.5\end{array}$ & $\begin{array}{r}(36) \\
(84) \\
(56) \\
(40) \\
(9)\end{array}$ & $\begin{array}{l}{[56 \cdot 9-88 \cdot 2]} \\
{[63 \cdot 5-83 \cdot 8]} \\
{[53 \cdot 8-80 \cdot 7]} \\
{[55 \cdot 1-86 \cdot 3]} \\
{[27 \cdot 2-91 \cdot 8]}\end{array}$ \\
\hline
\end{tabular}

mitted chlamydial infection, which are needed to plan prevention and control activities.

\section{Acknowledgements}

Principal Investigators: Luis Rosero-Bixby, Mark W Oberle, MD; Project Coordinators: Carmen Grimaldo, Lic; Martin Fallas; Daisy Fernández, MD; Data Managers: Anne S Whatley, MS; Harnán Caamano; Elizabeth Z Rovira, MStat; A H Rampey, Jr, MS, Steve Kinchen; Project Associates: Oscar Fallas, MD; Nancy C Lee, MD; Kathleen L Irwin, MD; Judith A Fortney, PhD; Gary S Grubb, MD; Michele G Bonhomme, MSPH; Project Consultants: Raimundo Riggioni, MD; Miguel Gómez, MS; Phyllis A Wingo, MS; George L Rubin, MBBS; Howard W Ory, MD; Peter M Layde, MD; Jacquelyn Arthur; Emilia Leon, MD; Costa Rican National Tumor Registry: Georgina Muñoz de Brenes; Laboratory Consultants: Mary E Guinan, MD, PhD; Jorge Ramirez; Sandra Larsen, PhD; Andre J Nahmias, MD; Julius Schachter, PhD; Pathology Consultants: Saeed Mekbel, MD; Jorge Salas Cordero, $\mathrm{MD}$; León Trópper, $\mathrm{MD}$.

This study was supported in part by Family Health International, Research Triangle Park, NC, USA with funds from the US Agency for International Development. Opinions expressed in this paper do not necessarily represent those of US AID. The MIF testing was supported by US Public Health Service STD program project grant AI21912. Additional support for this analysis was provided by The William and Flora Hewlett Foundation.

Address correspondence to: Kathleen M Vetter, International Health Track, Division of Public Health, Emory University, Atlanta, GA 30322, USA

1 Thompson SE, Washington AC. Epidemiology of sexually transmitted Chlamydia trachomatis infections. Epidemiol Rev 1983;5:96-123.

2 Judson FN. Epidemiology and control of nongonococcal urethritis and genital chlamydial infections: a review. Sex Transm Dis 1981;8(Suppl.): 117-26.

3 Irwin KL, Rosero-Bixby L, Oberle MW, et al. Oral contraceptives and cervical cancer risks in Costa Rica: detection bias or causal association? JAMA 1988;259:59-64, with correction JAMA 259:1182.

4 Lee NC, Rosero-Bixby L, Oberle MW, Grimaldo C, Whatley AS, Rovira EZ. A case-control study of breast cancer and hormonal contraception in Costa Rica. Journal of the National Cancer Institute 1987;79:1247-54.

5 Oberle MW, Rosero-Bixby L, Irwin KL, et al. Cervical cancer risk and use of Depot-Medroxyprogesterone acetate in Costa Rica. Int J Epidemiol 1988;17:718-23.

6 Centers for Disease Control Cancer and Steroid Hormone Study Group. Oral contraceptive use and the risk of breast cancer. $N$ Engl J Med 1986;315:405-11.

7 Wang SP, Grayston JT, Alexander ER, Holmes KK. Simplified microimmunofluorescence with trachoma-lymphogranuloma venereum (Chlamydia trachomatis) antigens for use as a screening test for antibody. J Clin Microbiol 1975;1:250-5.
8 Coffey EM, Bradford LL, Naritomi LS, Wood RM. Evaluation of the qualitative and automated quantitative microhemag glutination assay for antibodies to Treponema pallidum. Applied Microbiology 1972;24:26-30.

9 Nahmias AJ, Lee FK, Pereira L, Reid E, Wickliffe C. Monoclonal antibody immunoaffinity purified glycoproteins for the detection of herpes simplex virus Type 1 and Type 2 specific antibodies in serum. In: Lopez C, Roizman B, eds. Human Herpesvirus Infections. New York: Raven Press, 1986:203-10.

10 Shah BV. SESUDAAN: Standard errors program for computing of standardized rates from sample survey data. Research Triangle Park, NC: Research Triangle Institute, 1981:25-33.

11 Ramirez JA, Rosero-Bixby L, Oberle MW. Susceptibilidad al tétanos y rubeola de las mujeres de Costa Rica, 1984-85. Costarricense de Ciencias Medicas (in press)

12 Nsanze H, Waigwa SRN, Mirza N, Plummer F, Roelants P, Piot P. Chlamydial infections in selected populations in Kenya. In: Mardh PA, Holmes KK, Oriel JD, Piot P, Schachter J, eds. Chlamydial Infections. Amsterdam: Elsevier, 1982:421-4.

13 Mårdh PA, Lind I, From E, Anderson AL. Prevalence of Chlamydia trachomatis and Neisseria gonorrhoeae infections in Greenland. A seroepidemiological study. Br J Venereal Dis 1980;56:327-31.

14 Darougar S, Forsey T, Osoba AO, Dines RI, Adelusi B, Coker GO. Chlamydial genital infection in Ibadan, Nigeria. A seroepidemiological survey. BrJ Venereal Dis 1982;58:366-9.

15 Bentsi C, Klufio CA, Perine PL, et al. Genital infections with Chlamydia trachomatis and Neisseria gonorrhoeae in Ghanaian women. Genitourin Med 1985;61:48-50.

16 Darougar S, Forsey T, Brewerton DA, Rogers KL. Prevalence of antichlamydial antibody in London blood donors. $\mathrm{Br}$ Venereal Dis 1980;56:404-7.

17 Numazaki K, Chiba S, Nakata S, Yamanaka T, Nakao T Prevalence of antibodies to Chlamydia trachomatis in Japanese persons determined by microimmunofluorescence using reticulate bodies as single antigen. Pediatr Infect Dis $J$ 1984;3:105-9.

18 Wang SP, Grayston JT, Kuo CC, Alexander ER, Holmes KK. Serodiagnosis of Chlamydia trachomatis infection with the microimmunofluorescence test. In: Hobson D, Holmes KK, eds. Nongonococcal Urethritis and Related Infections. Washington DC: American Society for Microbiology, 1977:237-48.

19 Kuo CC, Chen HH, Wang SP, Grayston JT. Identification of a new group of Chlamydia psittaci strains called TWAR. J Clin Microbiol 1986;24:1034-7.

20 Grayston JT, Kuo CC, Wang SP, Altman J. A new Chlamydia psittaci strain, TWAR, isolated in acute respiratory tract infections. N Engl J Med 1986;315:161-8.

21 Grayston JT, Juo C-C, Campbell LA, Wang S-P. Chlamydio pneumoniae sp. nov. for Chlamydia sp. strain TWAR. International Journal of Systematic Bacteriology 1989;39:88-90.

22 Burney P, Forsey T, Darougar S, Sittampalam Y, Booth P Chamberlain $R$. The epidemiology of chlamydial infections in childhood: a serological investigation. Int J Epidemiol 1984; 13:491-5.

23 San Joaquin VH, Rettig PJ, Newton JY, Marks MI. Prevalence of chlamydial antibodies in children. Am J Dis Child 1982; 136:425-7.

24 Schachter J, Grossman M, Sweet RL, Holt J, Jordan C, Bishop E. Prospective study of perinatal transmission of Chlamydia trachomatis. JAMA 1986;225:3374-7. 
25 Schachter J. Human Chlamydia psittaci infection. In: Oriel D, Ridgway G, Schachter J, Taylor-Robinson D, Ward M, eds. Chlamydial Infections. Cambridge: Cambridge University Press, 1986:311-20.

26 Wang SP, Grayston JT. Microimmunofluorescence serological studies with the TWAR organism. In: Oriel D, Ridgeway G Schachter J, Taylor-Robinson D, Ward M, eds. Chlamydia Infections. Cambridge: Cambridge University Press, 1986: $329-32$.

27 Black SB, Grossman M, Cles L. Serologic evidence of chlamydial infection in children. $J$ Pediatr 1981 ;98:65-7.

28 McComb DE, Nichols RL, Semine DZ, et al. Chlamydia trachomatis in women: antibody in cervical secretions as a possible indicator of genital infection. $J$ Infect Dis 1979; 139:628-33.

29 Puolakkainen M, Vesterinen E, Purola E, Saikku P, Paavonen J. Persistence of chlamydial antibodies after pelvic inflammatory disease. J Clin Microbiol 1986;23:924-8.

30 Aral SO, Mosher WD, Cates W. Self-reported pelvic inflammatory disease in the US: a common occurrence. Am J Public Health 1985;75:1216-8.

31 Fuentes L, Somogyi T, Murillo F. Evidencia de infección por Chlamydia trachomatis en Costa Rica. Rev Latam Microbiol 1986;28:117-9.

32 Farrow JM, Mahony JB. Chlamydial pneumonia in Costa Rica: results of a case-control study. Bull WHO 1988;66:365-8. 